\title{
ANALISIS PERBANDINGAN EFISIENSI PRODUKSI PADI SAWAH: ANTARA SISTEM TANAM JAJAR LEGOWO DAN SISTEM TANAM KONVENSIONAL
}

A Comparative Analysis on Paddy Field Production Efficiency: Between Legowo Planting Systems and Conventional Planting Systems

\author{
ARDI GUSTRI PURBATA ${ }^{\mathbf{1}}$, SYAIFUL HADI ${ }^{2}$, SUARDI TARUMUN ${ }^{3}$ \\ $1,2,3$ Program Pascasarjana, Magister Agribisnis, Universitas Riau \\ Kampus Bina Widya KM. 12.5, Simpang Baru, Kec. Tampan, Kota Pekanbaru, Riau 28293 \\ E-mail: ardigustri@gmail.com
}

\begin{abstract}
ABSTRAK
Penelitian ini bertujuan untuk menganalisis secara teknis budidaya padi sawah jajar legowo dan sistem tanam konvensional, menganalisis usahatani, mencari efisiensi produksi dan membandingkan efisiensi produksi padi sawah jajar legowo dan sistem tanam konvensional. Penelitian ini dilakukan dengan metode survei dan penentuan sampel dilakukan secara multistage sampling dengan jumlah responden 126 petani padi sawah yang berada di Kabupaten Kuantan Singingi dengan menggunakan alat analisis yaitu analisis deskriptif, analisis usahatani, DEA (Data Envelopment Analysis) dan analisis independent sample test. Hasil penelitian menunjukkan bahwa secara teknis budidaya padi sawah jajar legowo dan sistem tanam konvensional sesuai dengan standar yang diberikan para ahli. Untuk usahatani, sistem tanam padi sawah jajar legowo memiliki RCR sebesar 1,954 dan sistem tanam konvensional sebesar 1,777, ini berarti sistem tanam jajar legowo lebih menguntungkan dari pada sistem tanam konvensional. Perbandingan efisiensi produksi antara padi sawah jajar legowo dan sistem tanam konvensional yaitu terdapat perbedaan yang signifikan baik efisiensi teknis, efisiensi alokatif dan efisiensi ekonomis.
\end{abstract}

Kata Kunci : Data Envelopment Analysis, Efisiensi Produksi Padi, Jajar Legowo, Konvensional

\begin{abstract}
This study was aimed to analyze technically the cultivation of paddy jajar legowo planting systems and conventional planting systems, analyze of farming, look for production efficiency and compare the efficiency of the production of jajar legowo planting systems and conventional planting systems. This study was conducted by survey method and the determination of the sample was carried out by multistage sampling with 126 respondents of lowland rice farmers in Kuantan Singingi District using analytical tools namely descriptive analysis, farm analysis, DEA (Data Envelopment Analysis) and independent sample test analysis. The results of the study showed that technically the pady cultivation of jajar legowo planting systems and conventional planting systems were in accordance with the standards that was given by experts. For farming, the paddy of jajar legowo planting system has an RCR of 1.954 and a conventional planting system of 1.777, its means the jajar legowo planting system was more profitable than the conventional planting system. Comparison of production efficiency between paddy of jajar legowo planting systems and conventional planting systems were significant differences in technical efficiency, allocative efficiency and economic efficiency.
\end{abstract}

Keywords: Conventional, Data Envelopment Analysis, Jajar Legowo, Paddy Production Efficiency.

Diterima : 7 January 2020. Disetujui: 4 Februari 2020 


\section{PENDAHULUAN}

Krisis perekonomian yang terjadi di Indonesia menyebabkan masyarakat kesulitan dalam memenuhi kehidupan. Krisis global juga membuat krisis bertambah sulit, banyak kalangan yang memperkirakan kalau krisis perekonomian yang semakin kompleks ini bisa mengarah kepada krisis pangan.

Beras merupakan bahan pangan pokok bagi lebih dari 95 persen penduduk Indonesia. Konsumsi beras di Indonesia semakin meningkat setiap tahunnya seiring dengan meningkatnya jumlah penduduk Indonesia. Kekurangan Pangan bisa menyebabkan kerawanan ekonomi, sosial, dan politik yang dapat menggoyahkan stabilitas nasional.

Penurunan lahan sawah akibat alih fungsi untuk kepentingan non pertanian, dan produksi sawah irigasi cenderung menurun. Upaya untuk meningkatkan produksi pertanian padi telah banyak dilakukan baik oleh pemerintah, lembaga swadaya masyarakat, dan perguruan tinggi.

Peningkatan produksi padi dilakukan dengan berbagai kebijakan, seperti: pembangunan sarana irigasi, subsidi benih, pupuk, dan pestisida, kredit usahatani bersubsidi, dan pembinaan kelembagaan usahatani telah ditempuh.

Upaya pencapaian target program Peningkatan Produksi Beras Nasional (P2BN) pemerintah dalam hal ini Departemen Pertanian melalui Badan Pengembangan dan Penelitian telah banyak mengeluarkan rekomendasi untuk diaplikasikan oleh petani. Salah satunya adalah penerapan sistem tanam untuk meningkatkan produksi padi.

Teknologi jajar legowo merupakan suatu pola tanam dengan mengatur jarak tanam padi yang bertujuan untuk meningkatkan produksi padi. Pola tanam ini berselang seling antara dua atau lebih baris tanaman padi dan satu baris kosong. Pada musim tanam 2016, di Kabupaten Indramayu Jawa Barat, teknologi jajar legowo telah diuji pada demarea seluas 50 ha.

Berdasarkan hasil panen ubinan, dihasilkan bahwa terdapat berbagai varietas unggul yang mempunyai potensi produksi tinggi. Diantaranya ialah varietas inpari 30 dan Ciherang dengan potensi 13,9 ton GKP/ha, varietas inpari $32 \mathrm{HBD}$ dengan potensi 14,4 ton GKP/ha, dan varietas inpari 33 dengan potensi 12,4 ton GKP/ha (Balitbang Pertanian, 2016).

Kabupaten Kuantan Singingi sudah menjadi salah satu sentra produksi padi yang cukup berpotensi di Propinsi Riau. Luas area Panen padi sawah di Kabupaten Kuantan Singingi merupakan yang terbesar ketiga di Provinsi Riau yaitu sebesar $11.175 \mathrm{Ha}$. Produksi padi sawah di Kabupaten Kuantan Singingi merupakan terbesar kedua yaitu sebesar 50.125 Ton.

Petani di Kabupaten Kuantan Singingi umumnya menggunakan sistem tanam jajar legowo dan sistem tanam konvensional. Sebagian besar petani di Kabupaten Kuantan Singingi masih menggunakan sistem tanam konvensional.

Faktor yang menyebabkan petani masih mempertahankan sistem konvensional dikarenakan sulit menerima sistem baru dan lebih memilih menggunakan sistem konvensional secara turun temurun, kurangnya informasi tentang teknologi terbaharukan, dan rendahnya tingkat pendidikan. 


\section{METODOLOGI PENELITIAN Tempat dan Waktu Penelitian}

Penelitian ini dilaksanakan di Kabupaten Kuantan Singingi Provinsi Riau. Kabupaten ini ditentukan secara sengaja dengan pertimbangan bahwa kabupaten ini memiliki luas panen terbesar ketiga dan produksi padi sawah terbesar kedua di Provinsi Riau.

\section{Pengambilan Sampel dan Data}

Metode sample yang digunakan dalam penelitian ini yaitu metode multistage sampling. Penentuan lokasi dipilih secara bertahap dimulai dari kabupaten yaitu Kabupaten Kuantan Singingi. Penentuan kecamatan dipilih yaitu: Kecamatan Kuantan Tengah, Kecamatan Gunung Toar, dan Kecamatan Kuantan Hilir. Setiap kecamatan diambil 3 desa sampel, dimana masing-masing desa diambil 14 sampel intensity yang terdiri dari 7 sampel petani jajar legowo dan 7 petani konvensional. Sehingga jumlah sampel seluruhnya adalah 126 sampel petani.

Data yang diambil terdiri dari data primer yang diperoleh melalui wawancara secara langsung menggunakan daftar pertanyaan (kuisioner). Data sekunder yang diperoleh dari instansi terkait yaitu dari Kantor Camat, Dinas Pertanian Provinsi Riau dan Kabupaten Kuantan Singingi, Badan Pusat Statistik (BPS), serta literatur-literatur lainnya yang terkait dengan penelitian.

\section{Metode Analisis Data}

Metode analisis yang digunakan pada penelitian ini adalah metode analisis deskriftif, metode analisis usahatani, metode analisis DEA (Data Envelopment Analysis) dan metode analisis perbandingan (Independent Sample Test).

Penerapan Teknis Budidaya Padi Sawah
Analisis teknis budidaya yang ditemui pada petani padi sawah di Kabupaten Kuantan Singingi dan dibandingkan dengan teknis budidaya yang standar menurut text book dan GAP (Good Agricultural Practices). Metode yang digunakan untuk menjawab dari tujuan penelitian ini adalah metode analisis deskriptif.

Analisis Usahatani Padi Sawah

Usahatani padi sawah di

Kabupaten Kuantan Singingi dianalisis dengan menghitung biaya produksi, penerimaan, pendapatan, dan RCR usahatani. Pendapatan (income) dihitung dengan cara mengurangkan total penerimaan dengan total biaya, dengan rumus sebagai berikut:

$$
\Pi=\mathrm{TR}-\mathrm{TC}
$$

dimana:

$\Pi=$ Pendapatan usahatani padi sawah (Rp)

$\mathrm{TR}=$ Total penerimaan usahatani padi sawah (Rp)

$\mathrm{TC}=$ Total biaya usahatani padi sawah (Rp)

Kelayakan usaha tani dapat diukur dengan membandingkan besarnya penerimaan dengan total biaya yang dikeluarkan dalam usahatani padi sawahh tersebut.

$$
\mathrm{RCR}=\mathrm{TR} / \mathrm{TC}
$$

dimana:

$\mathrm{RCR}=$ Revenue Cost Ratio usahatani padi sawah

$\mathrm{TR}=$ Total penerimaan usahatani padi sawah (Rp)

$\mathrm{TC}=$ Total biaya usahatani padi sawah (Rp)

Dengan kriterianya adalah:

RCR $>1 \Rightarrow$ Usahatani padi sawah dikatakan menguntungkan

RCR $<1 \Rightarrow$ Usahatani padi sawah dikatakan tidak menguntungkan

$\mathrm{RCR}=1 \Rightarrow$ Usahatani padi sawah dikatakan pada keadaan impas. 


\section{Analisis Efisiensi Produksi}

Analisis efisiensi produksi usahatani padi sawah di Kabupaten Kuantan Singingi menggunakan metode DEA. Pengukuran efisiensi menggunakan analisis Data Envelopment Analysis (DEA). Pada konsep DEA, nilai efisiensi yang dihasilkan bersifat relatif atau hanya berlaku dalam lingkup petani padi sawah yang menjadi DMU (Decision Making Unit) yang diperbandingkan tersebut.

Variabel keputusan adalah bobot yang harus diberikan pada setiap unit input dan output oleh petani $V_{\text {ik }}$ adalah bobot yang diberikan pada unit i oleh kegiatan $\mathrm{k}$ dan $\mathrm{U}_{\mathrm{rk}}$ merupakan variable keputusan, yakni variabel yang nilainya akan ditentukan melalui program linier fraksional, suatu formulasi program linier untuk setiap DMU dalam sampel. Fungsi tujuan (objective function) dari setiap linier program fraksional tersebut adalah rasio dari output tertimbang total (total weighted output) dari petani dibagi dengan input tertimbang totalnya (Dendawijaya, 2001). Formulasi fungsi tujuan tersebut adalah:

Maksimumkan:

$$
z_{k}=\frac{\sum_{r}^{S}}{\sum_{i}^{m}}=\frac{1 U_{r k Y_{r k}}}{1 V_{i k} X_{i k}}
$$

dimana:

$\mathrm{Z}_{\mathrm{k}}=$ efisiensi teknis usahatani padi sawah

Kriteria universalitas mensyaratkan petani untuk memiliki bobot dengan batasan atau kendala bahwa tidak ada satu petani lain yang akan memiliki efisiensi lebih besar dari 1 atau $100 \%$, sehingga formulasi selanjutnya adalah:

$$
\begin{gathered}
\frac{\sum_{r}^{S}}{\sum_{i}^{m}}=\frac{1 U_{r k} Y_{r k}}{1 V_{i k} X_{i k}} \leq \mathrm{i}, \mathrm{i}=1 \ldots, \mathrm{n} \\
U_{r k} \geq 0 ; \mathrm{r}=1, \ldots \ldots \mathrm{s} \\
V_{i k} \geq 0 ; \mathrm{r}=1, \ldots \ldots \mathrm{m}
\end{gathered}
$$

dimana :

$\mathrm{n} \quad=$ Jumlah sampel

$\mathrm{s} \quad=$ Petani yang dianalisis

$\mathrm{m}=$ Jumlah input

Program transaksi linier kemudian ditransformasikan kedalam linier biasa (ordinary linier program) dengan metode simpleks untuk menyelesaikannya. Transformasi tersebut adalah sebagai berikut:

1) CRS (Constan Return to Scale) Maksimumkan:

$$
Z_{k}=\sum_{r}^{s}=1 U_{r k} Y_{r k}
$$

Dengan kendala :

$$
\begin{gathered}
\sum_{r}^{s}=1 U_{r k} Y_{r k}-\sum_{i}^{m}= \\
1 V_{i k} X_{i k} \leq 0 ; \mathrm{j}=1 \ldots . \mathrm{n} \\
U_{r k} \geq ; \mathrm{r}=1, \ldots \mathrm{s} \\
V_{i k} \geq ; \mathrm{i}=1, \ldots \mathrm{s}
\end{gathered}
$$

dimana:

$\mathrm{Y}_{\mathrm{rk}}=$ Jumlah output yang dihasilkan petani

$\mathrm{X}_{\mathrm{ik}}=$ Jumlah produksi yang diperlukan petani

$\mathrm{s}=$ Jumlah petani yang dianalisis

$\mathrm{m}=$ Jumlah input yang digunakan

$\mathrm{V}_{\mathrm{ik}}=$ Bobot tertimbang dari output beras yang dihasilkan oleh tiap petani

$\mathrm{Z}_{\mathrm{k}}=$ Nilai yang dioptimalkan sebagai indikator efisiensi relatif dari usahatani padi sawah yang menjadi sampel

2) VRS (Variable Return to Scale)

Maksimumkan:

$$
Z_{k}=\sum_{r}^{n}=1 U_{r k} Y_{r k}+U_{o}
$$

Dengan batasan:

$$
\begin{gathered}
\sum_{r}^{n}=1 U_{r k} Y_{r k}-\sum_{r}^{m}=1 V_{i k} X_{i k} \\
\leq 0 ; \mathrm{j}=1 \ldots \ldots \mathrm{n} \\
U_{r k} \geq ; \mathrm{r}=1, \ldots \ldots \ldots \mathrm{n} \\
V_{i k} \geq ; \mathrm{i}=1, \ldots \ldots \ldots \mathrm{n}
\end{gathered}
$$

dimana:

$\mathrm{U}_{\mathrm{o}}=$ variable keputusan yang dapat

bernilai positif atau negatif 
Model VRS beranggapan bahwa petani tidak atau belum beroperasi pada skala yang optimal. Asumsi dari model ini adalah bahwa rasio antara penambahan input dan output tidak sama. Artinya, penambahan input sebesar X kali tidak akan atau belum tentu menyebabkan output meningkat sebesar X kali, bisa jadi lebih kecil atau lebih besar dari $\mathrm{X}$ kali. Hubungan antara efisiensi teknis, efisiensi alokatif, dan efisiensi ekonomis adalah sebagai berikut (Soekartawi, 2002) :

dimana:

$$
\mathrm{EE}=\mathrm{ET} \times \mathrm{EH}
$$

$\mathrm{EE}=$ efisiensi ekonomi
ET $=$ efisiensi teknik

$\mathrm{EH}=$ efisiensi harga

\section{Independent Sample T-Test}

Analisis perbandingan dengan mengggunakan (Uji t) bertujuan untuk mengetahui seberapa besar perbedaan efisiensi produksi (teknis, alokatif, ekonomi) antara padi sawah sistem jajar legowo dan sistem tanam konvensional di Kabupaten Kuantan Singingi. Analisis uji perbandingan ini didasarkan atas bentuk hipotesis sebagai berikut :$$
\text { Dimana : }
$$

$$
\mathrm{H}_{0}: \mu_{1} \geq \mu_{2} \text { lawan } \mathrm{H}_{1}: \mu_{1}<\mu_{2}
$$

$\mu_{1}=$ Rata-rata efisiensi produksi padi sawah konvensional

$\mu_{2}=$ Rata-rata efisiensi produksi padi sawah jajar legowo

$\mathrm{H}_{0}=$ Rata-rata efisiensi produksi padi sawah sistem tanam konvensional lebih besar atau sama dengan rata-rata efisiensi produksi pada padi sawah sistem tanam jajar legowo

$\mathrm{H}_{1}=$ Rata-rata efisiensi produksi padi sawah sistem tanam konvensional lebih kecil dari rata-rata efisiensi produksi padi sawah sistem tanam jajar legowo
Data dianalisis secara kuantitatif digunakan analisis Uji $\mathrm{T}$ Test (Independent Sample T Test) dengan rumus :

Keterangan:

$$
\mathrm{t}=\frac{X-\mu}{S / \sqrt{ } n}
$$

$\mathrm{t}=$ Nilai hitung $\mathrm{t}$

$X=$ Rata-rata sampel (mean)

$\mu=$ Rata-rata populasi

$\mathrm{S}=$ Standar deviasi sampel

$\mathrm{n}=$ Jumlah observasi di dalam sampel

\section{HASIL DAN PEMBAHASAN Teknis Budidaya Padi Sawah}

Teknis budidaya yang dilihat antara rekomendasi para ahli dengan realita di lapangan adalah : varietas dan benih, persemaian, pengolahan lahan, pupuk organik, penanaman, pengairan, pemeliharaan, pemupukan anorganik, hama dan penyakit, panen dan pasca panen. Petani padi sawah jajar legowo di Kabupaten Kuantan Singingi sudah melakukan budidaya sesuai dengan standar yang ditetapkan oleh para ahli dengan nilai kesesuaian sebesar 81 persen. Petani padi sawah konvensional di Kabupaten Kuantan Singingi sudah melakukan budidaya sesuai dengan standar yang telah dianjurkan para ahli dengan besaran nilai kesesuaian adalah sebesar 86 persen.

\section{Analisis Usahatani Padi Sawah}

Total biaya dari usahatani terdiri dari biaya tetap (fixed cost) dan biaya tidak tetap (variable cost). Biaya tetap terdiri dari penyusutan alat, upah TKDK, dan nilai sewa lahan, sedangkan biaya variabel meliputi biaya benih, pupuk organik, pupuk anorganik, pestisida, upah TKLK, sewa pemakaian hand traktor, perontokan, dan penggilingan. Rata-rata alokasi biaya produksi usahatani padi sawah di Kabupaten Kuantan Singingi dapat dilihat dalam Tabel 1. 
Tabel 1. Rata-Rata Alokasi Biaya Produksi Usahatani Padi Sawah Per Musim Tanam

\begin{tabular}{|c|c|c|c|c|c|}
\hline \multirow{2}{*}{ No } & \multirow{2}{*}{ Alokasi Biaya } & \multicolumn{2}{|c|}{ Jajar legowo } & \multicolumn{2}{|c|}{ Konvensional } \\
\hline & & Rp/LG & $\mathrm{Rp} / \mathrm{Ha}$ & Rp/LG & Rp/Ha \\
\hline \multirow[t]{4}{*}{1} & Biaya Tetap & & & & \\
\hline & a. Penyusutan Alat & 37.116 & 148.510 & 34.492 & 125.434 \\
\hline & b. Upah TKDK & 1.579 .768 & 5.226 .487 & 1.754 .998 & 5.506 .196 \\
\hline & c. Lahan & 1.009 .524 & 3.000 .000 & 1.030 .952 & 3.000 .000 \\
\hline \multirow[t]{10}{*}{2} & Biaya Variabel & & & & \\
\hline & a. Biaya Benih & 135.675 & 405.504 & 122.159 & 356.488 \\
\hline & b. Biaya Pupuk Organik & 347.460 & 1.039 .506 & 315.873 & 919.671 \\
\hline & c. Biaya Pupuk Anorganik & 286.976 & 879.271 & 238.730 & 684.307 \\
\hline & d. Biaya Pestisida & 55.639 & 164.498 & 58.385 & 164.286 \\
\hline & e. Upah TKLK & 141.714 & 184.163 & 128.000 & 166.313 \\
\hline & $\begin{array}{l}\text { f. Sewa Pemakaian Hand } \\
\text { Traktor }\end{array}$ & 968.103 & 2.890 .952 & 909.349 & 2.627 .619 \\
\hline & $\begin{array}{l}\text { g. Sewa Pemakaian } \\
\text { Perontokan }\end{array}$ & 575.187 & 1.732 .202 & 504.821 & 1.476 .956 \\
\hline & $\begin{array}{l}\text { h. Sewa Pemakaian } \\
\text { Penggilingan }\end{array}$ & 1.380 .448 & 4.157 .285 & 1.211 .571 & 3.544 .694 \\
\hline & Jumlah & 6.517 .609 & 19.828 .378 & 6.309 .332 & 18.571 .963 \\
\hline
\end{tabular}

Sumber : Data Olahan, 2019

Rata-rata produksi padi sawah jajar legowo di Kabupaten Kuantan Singingi adalah $6.298,92 \mathrm{~kg}$ GKP per musim tanam per hektar, sedangkan rata-rata produksi padi sawah konvensional adalah $5.370,75 \mathrm{~kg}$ GKP per musim tanam per hektar. Selanjutnya GKP (Gabah Kering Panen) dirontok dan digiling sehingga dihasilkan beras dan sekam. Beras dihasilkan rata-rata sebanyak 3.779,35 $\mathrm{kg}$ per musim tanam per hektar untuk petani padi sawah jajar legowo dan $3.233,45 \mathrm{~kg}$ per musim tanam per hektar untuk petani padi sawah konvensional.

Hasil produksi padi sawah yang dikelola sebagian masih untuk konsumsi sendiri dan sebagian lagi dijual untuk menutupi kebutuhan non beras dan biaya untuk produksi selanjutnya dalam bentuk beras dengan harga Rp. 11.000 per kilogram dan sekam dengan harga Rp. 500 per kilogram. Untuk mengetahui bahwa usahatani padi sawah jajar legowo sudah mendapatkan keuntungan bagi petani atau belum, perlu dilakukan perhitungan dengan cara penerimaan dikurangi dengan biaya produksi yang dikeluarkan keseluruhan.

Total biaya produksi rata-rata yang dibutuhkan petani padi sawah jajar legowo adalah sebesar $\mathrm{Rp}$. 19.828.378 per musim tanam per hektar, sedangkan penerimaan rata-rata sebesar Rp. 38.675.348 per musim tanam per hektar, sehingga rata-rata pendapatan bersih (keuntungan) yang didapat sebesar Rp. 18.846.970 per musim tanam per hektar. Total biaya produksi rata-rata petani padi sawah konvensional adalah sebesar Rp. 18.571.961 per musim tanam per hektar, sedangkan penerimaan rata-rata sebesar Rp. 32.976.395 sehingga ratarata pendapatan bersih (keuntungan) yang didapat sebesar Rp. 14.404.431.

Return Cost Ratio (RCR) yaitu membandingkan antara penerimaan selama satu periode tanam dengan biaya produksi selama satu periode tanam. Untuk lebih jelasnya mengenai produksi, pendapatan, dan RCR petani padi sawah dapat dilihat pada Tabel 2 di bawah ini 
Tabel 2. Rata-Rata Penerimaan, Biaya Produksi, Pendapatan, dan RCR Usahatani Padi Sawah per Musim Tanam

\begin{tabular}{|c|c|c|c|c|c|}
\hline \multirow{3}{*}{ No } & \multirow{3}{*}{ Uraian } & \multicolumn{4}{|c|}{ Rataan Biaya } \\
\hline & & \multicolumn{2}{|c|}{ Jajar Legowo } & \multicolumn{2}{|c|}{ Konvensional } \\
\hline & & RP/LG & RP/Ha & RP/LG & RP/Ha \\
\hline 1 & Penerimaan (TR) & & & & \\
\hline \multirow{7}{*}{2} & a. Beras & 12.424 .029 & 37.415 .565 & 10.904 .143 & 31.902 .245 \\
\hline & b. Sekam & 418.317 & 1.259 .783 & 367.143 & 1.074 .150 \\
\hline & Total Penerimaan (TR) & 12.842 .346 & 38.675 .348 & 11.271 .286 & 32.976 .395 \\
\hline & Biaya Produksi (TC) & & & & \\
\hline & a. Biaya Tetap & 2.626 .408 & 8.374 .997 & 2.820 .442 & 8.631 .630 \\
\hline & b. Biaya Variabel & 3.891 .201 & 11.467 .381 & 3.488 .801 & 9.940 .331 \\
\hline & Total Biaya Produksi (TC) & 6.517 .609 & 19.828 .378 & 6.309 .332 & 18.571 .963 \\
\hline 3 & $\begin{array}{l}\text { Pendapatan Bersih } \\
\text { (Keuntungan) }\end{array}$ & 6.324 .737 & 18.846 .970 & 4.961 .954 & 14.404 .432 \\
\hline 4 & $\mathrm{RCR}$ & 1,954 & 1,954 & 1,777 & 1,777 \\
\hline
\end{tabular}

Sumber : Data Olahan, 2019

RCR petani padi sawah jajar legowo adalah 1,954 untuk dan 1,777 untuk petani padi sawah konvensional. Maka dapat dikatakan usahatani padi sawah jajar legowo dan sistem tanam konvensional di Kabupaten Kuantan Singingi menguntungkan.
Analisis biaya produksi merupakan salah satu indikator kedayasaingan. Hasil analisis biaya produksi padi sawah jajar legowo di Kabupaten Kuantan Singingi dibandingkan dengan biaya produksi padi sawah konvensional di Kabupaten Kuantan Singingi. Perbandingan keduanya dapat dilihat pada Tabel 3 .

Tabel 3. Perbandingan Biaya, Produksi, Penerimaan, Pendapatan, dan RCR Usahatani Padi Sawah Jajar Legowo dan Konvensional

\begin{tabular}{clrr}
\hline No & \multicolumn{1}{c}{ Uraian } & $\begin{array}{c}\text { Padi Sawah Jajar } \\
\text { Legowo }\end{array}$ & $\begin{array}{c}\text { Padi Sawah } \\
\text { Konvensional }\end{array}$ \\
\hline 1 & Biaya Produksi (Rp/MT/Ha) & 19.828 .378 & 18.571 .963 \\
2 & Hasil Produksi (Kg/MT/Ha) & $3.779,35$ & $3.233,45$ \\
3 & Biaya per Unit (Rp/Kg) & 5.247 & 5.743 \\
4 & Penerimaan (Rp/MT/Ha) & 38.675 .348 & 32.976 .395 \\
5 & Pendapatan (Rp/MT/Ha) & 18.846 .970 & 14.404 .432 \\
6 & RCR & 1,954 & 1,777 \\
\hline
\end{tabular}

Sumber : Data Olahan, 2019

Usahatani padi sawah jajar legowo memiliki tingkat kedayasaingan yang lebih tinggi dibandingkan dengan petani padi sawah konvensional. Hal ini terbukti dari produksi yang dihasilkan petani padi sawah jajar legowo lebih tinggi dibandingkan petani padi sawah konvensional, dimana produksi beras yang dihasilkan petani padi sawah jajar legowo sebanyak $3.779,35 \mathrm{~kg}$ per musim tanam per hektar, sedangkan produksi beras yang dihasilkan petani padi sawah konvensional sebanyak $3.233,45 \mathrm{~kg}$ per musim tanam per hektar sehingga biaya produksi per unit $(\mathrm{kg})$ beras yang dihasilkan petani padi sawah jajar legowo lebih rendah dibandingkan petani padi sawah konvensional. Hal ini menyebabkan petani padi sawah jajar legowo dapat menghasilkan penerimaan yang lebih tinggi sehingga keuntungan dan RCR yang didapat lebih besar dibandingkan dengan petani padi sawah konvensional. 


\section{Analisis Efisiensi Produksi: Teknis Padi Sawah}

Efisiensi teknis padi sawah jajar legowo berhubungan dengan faktorfaktor produksi yang menjadi input. Faktor produksi dalam usahatani padi sawah di Kabupaten Kuantan Singingi terdiri dari luas areal panen, benih, pupuk organik, pupuk anorganik, pestisida, dan tenaga kerja. Untuk melihat proporsi efisiensi teknis usahatani padi sawah disajikan dalam Gambar 1 berikut :

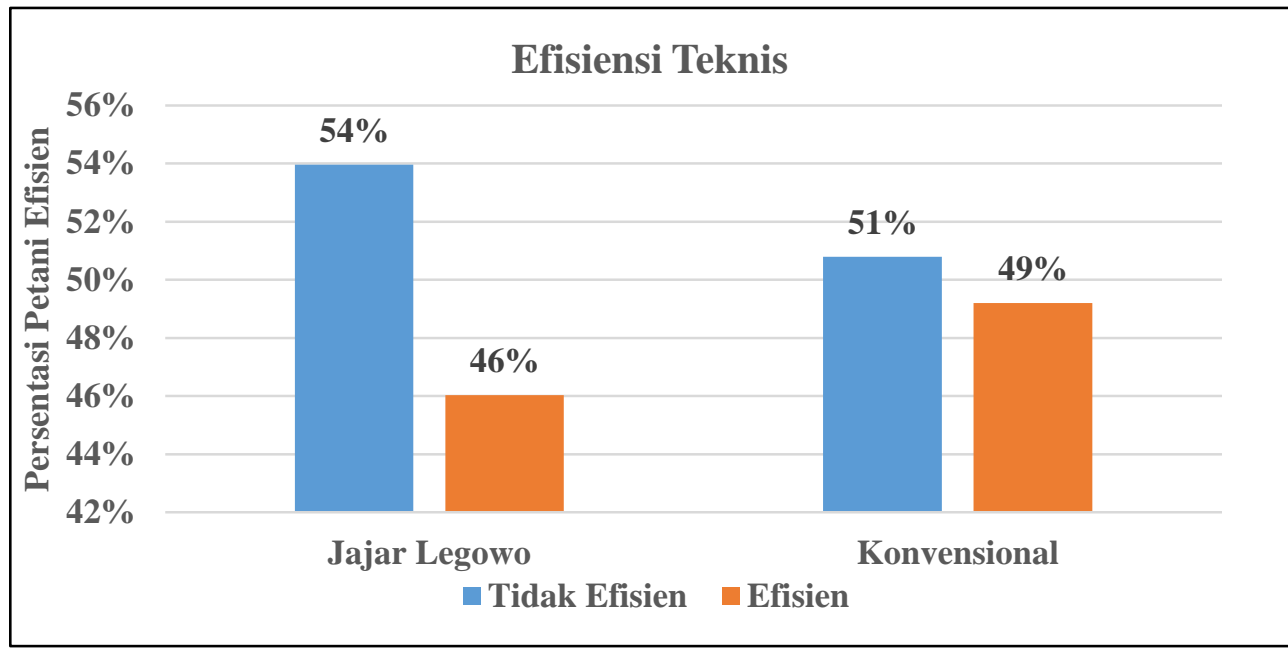

Gambar 1. Proporsi Efisiensi Teknis Usahatani Padi Sawah di Kabupaten Kuantan Singingi

Kelompok petani pada sistem tanam jajar legowo yang skor efisiensi satu atau mencapai efisiensi secara teknis yaitu sebanyak 46 persen atau 29 petani, sedangkan sebesar 54 persen atau 34 petani belum mencapai efisien secara teknis. Sebaran nilai efisiensi teknis padi sawah jajar legowo berada antara 0,810-1 dengan rata-rata 0,965. Kelompok petani sistem tanam konvensional yang skor efisiensi kurang dari satu atau belum mencapai efisiensi secara teknis yaitu sebanyak 51 persen atau 32 petani, sedangkan sebesar 49 perseni atau 31 petani sudah mencapai efisien secara teknis. Sebaran nilai efisiensi teknis padi sawah konvensional berada antara 0,787 - 1 dengan rata-rata 0,971 . Nilai ini menunjukkan bahwa efisiensi teknis tidak terlalu bermasalah dalam usahatani padi sawah di Kabupaten Kuantan Singingi.
Petani yang sudah efisien telah menggunakan dan mengkombinasikan semua input yang dipakai dalam usahatani secara benar, sehingga dapat menghasilkan output yang optimal.

\section{Analisis Efisiensi Alokatif}

Efisiensi alokatif merupakan kemampuan petani untuk menggunakan input dalam proporsi optimal terhadap harganya. Artinya petani dapat dikatakan efisien secara alokatif apabila mampu menghasilkan output dengan biaya seminimal mungkin dengan menggunakan input yang minimal.

Harga input yang digunakan merupakan harga dari setiap input dalam variabel. Untuk harga pupuk anorganik didapat dari harga masingmasing jenis pupuk anorganik yang ada seperti Urea, KCL, NPK Phonska, dan SP36, dan dicari harga rata-rata tertimbang pupuk anorganik yang digunakan petani dalam setiap kegiatan produksinya. 
Nilai efisiensi alokatif ini usahatani padi sawah disajikan dalam menggunakan model VRS. Untuk Gambar 2 berikut : melihat proporsi efisiensi alokatif

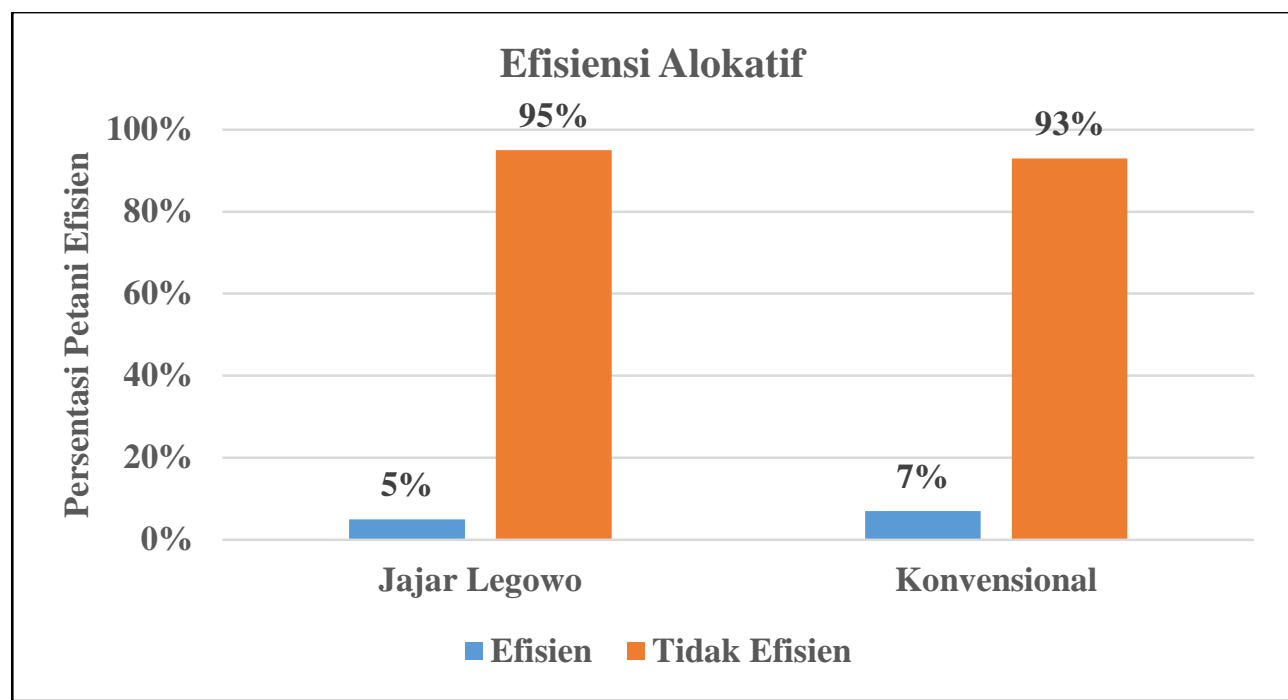

Gambar 2. Proporsi Efisiensi Alokatif Usahatani Padi Sawah di Kabupaten Kuantan Singingi

Data menunjukkan bahwa petani tidak efisien secara alokatif sekitar 5 persen petani padi sawah jajar legowo dan 7 persen petani padi sawah konvensional yang mampu mencapai tingkat efisiensi secara alokatif, hal ini berarti bahwa petani tersebut memiliki tingkat pengelolaan yang lebih baik jika dibandingkan dengan petani yang lainnya yang belum efisien.

Nilai efisiensi alokatif pada usahatani padi sawah jajar legowo di Kabupaten Kuantan Singingi berada pada kisaran 0,626 - 1 dengan rata-rata 0,840 , sedangkan pada usahatani padi sawah konvensional di Kabupaten Kuantan Singingi berada pada kisaran $0,572-1$ dengan rata-rata 0,783 . Proporsi terbanyak pada setiap sistem tanam adalah petani dengan skor efisiensi dibawah $<1$ yaitu petani padi sawah jajar legowo 60 petani dari 63 petani, dan petani padi sawah konvensional sebanyak 59 petani dari 63 petani, ini berarti bahwa sebagian besar petani padi sawah di Kabupaten Kuantan Singingi tidak efisien secara alokatif.

\section{Analisis Efisiensi Ekonomis}

Efisiensi ekonomis adalah hasil kombinasi dari efisiensi teknis dan efisiensi alokatif, artinya petani yang sudah efisien secara teknis dan alokatif berarti sudah efisien secara ekonomis.

Efisiensi ekonomis dapat tercapai apabila penggunaan faktor produksi sudah dapat menghasilkan sejumlah output yang telah ditentukan dengan penggunaan biaya yang telah ditentukan untuk mendapatkan keuntungan maksimum. Untuk melihat proporsi efisiensi ekonomis usahatani padi sawah disajikan dalam Gambar 3 berikut 


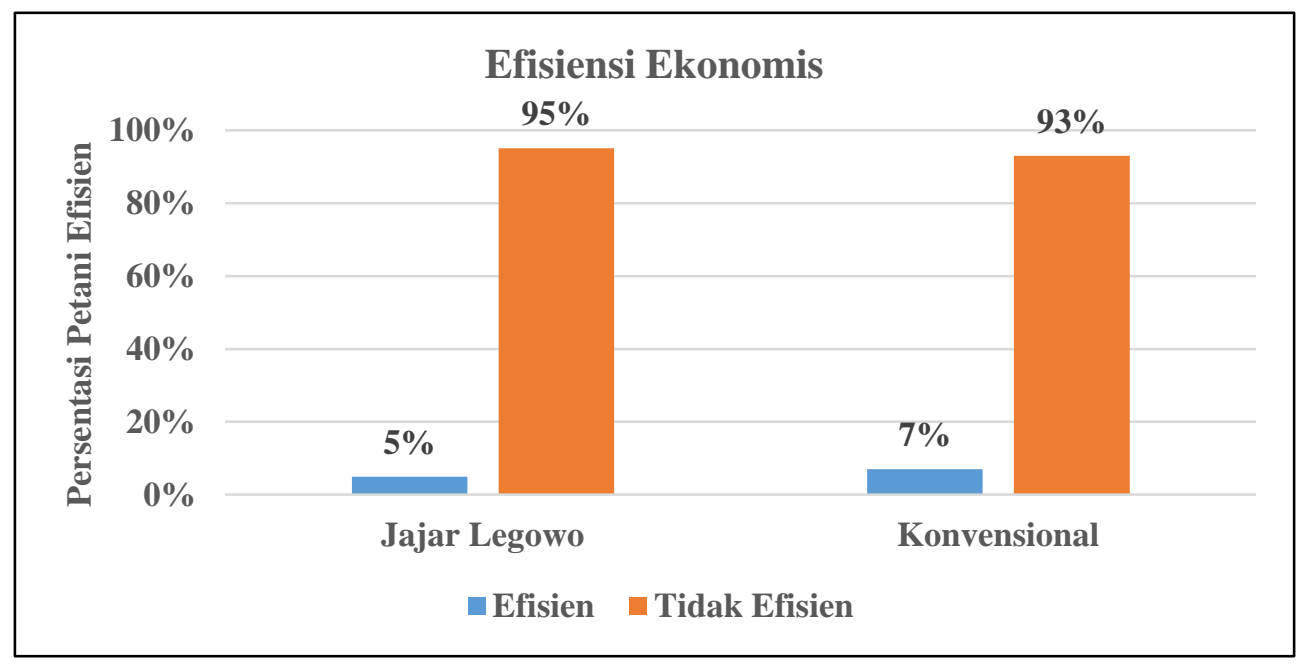

Gambar 3. Proporsi Efisiensi Ekonomis Usahatani Padi Sawah di Kabupaten Kuantan Singingi

Petani yang tidak efisien secara ekonomis pada usahatani padi sawah jajar legowo berjumlah 60 petani atau 95 persen, hal ini jauh lebih banyak dibandingkan dengan petani yang efisien yaitu berjumlah 3 petani atau 5 persen dengan nilai efisien berkisar antara 0,570 hingga 1,000 dengan ratarata 0,811. Petani yang tidak efisien secara ekonomis pada usahatani padi sawah konvensional berjumlah 59 petani atau 93,65 persen, hal ini jauh lebih banyak dibandingkan dengan petani yang efisien yaitu berjumlah 4 petani atau 6,35 persen dengan nilai efisien berkisar antara 0,572 hingga 1,000 dengan rata-rata 0,760 .

Petani yang belum efisien secara ekonomis menggambarkan bahwa petani tersebut belum bisa meminimalkan penggunaan input sehingga dengan input tertentu petani tersebut tidak dapat meminimalkan biaya input yang dikeluarkan, sedangkan jika efisiensi dapat dicapai, maka petani berpeluang untuk memperoleh pendapatan bersih yang lebih tinggi deengan jumlah produksi dan harga input tidak berubah.

\section{Perbandingan Efisiensi Produksi}

Uji independent sample T-Test digunakan untuk menentukan apakah dua sample yang tidak berhubungan memiliki nilai rata-rata yang berbeda. Dua kelompok yang dimaksud adalah efisiensi produksi usahatani padi sawah jajar legowo dengan jumlah sampel sebanyak 63 orang dan efisiensi produksi usahatani padi sawah konvensional dengan jumlah sampel sebanyak 63 orang di Kabupaten Kuantan Singingi. Dengan demikian jumlah sampel dari dua kelompok independen sebanyak 126 orang. Untuk melihat hasil perbandingan efisiensi produksi padi sawah dapat diilihat pada tabel 4 dibawah ini :

Tabel 4. Rekapitulasi Hasil Perbandingan Efisiensi Produksi Padi sawah jajar legowo dan Padi Sawah Konvensional

\begin{tabular}{llrrrl}
\hline & & Thitung & \multicolumn{1}{c}{ Ttabel } & \multicolumn{1}{c}{ Signifikan } & Keputusan \\
\hline \multirow{3}{*}{ Efisiensi } & Teknis &,- 793 & 1,980 &, 429 & H0 diterima \\
& Alokatif & 3,086 & 1,980 &, 003 & H1 diterima \\
& Ekonomis & 2,485 & 1,980 &, 014 & H1 diterima \\
\hline
\end{tabular}

Sumber : Data Olahan, 2019 
Petani padi sawah sistem tanam konvensional lebih efisien secara teknis dari pada petani padi sawah sistem tanam jajar legowo. Rata-rata efisiensi teknis petani padi sawah sistem tanam konvensional lebih besar dari petani padi sawah sistem tanam jajar legowo, dikarenakan dalam pengolahan ratarata petani padi sawah sistem tanam konvensional dalam penggunaan jarak tanam yang sesuai rekomendasi dari pada petani padi sawah sistem tanam jajar legowo sehingga dalam penggunaan benih dan pupuk lebih efisien.

Petani padi sawah sistem tanam jajar legowo lebih efisien secara alokatif dari pada petani padi sawah sistem tanam konvensional. Rata-rata efisiensi alokatif petani padi sawah sistem tanam jajar legowo lebih tinggi dibandingkan dengan petani padi sawah sistem tanam konvensional dikarenakan kemampuan petani padi sawah sistem tanam jajar legowo dalam menggunakan input dalam proporsi optimal terhadap harganya lebih optimal dibandingkan petani padi sawah sistem tanam konvensional.

Petani padi sawah sistem tanam jajar legowo lebih efisien secara alokatif dari pada petani padi sawah sistem tanam konvensional. Rata-rata efisiensi ekonomi petani padi sawah sistem tanam jajar legowo lebih tinggi dibandingkan dengan petani padi sawah sistem tanam konvensional dikarenakan penggunaan faktor produksinya lebih optimal. Efisiensi ekonomis dapat tercapai apabila penggunaan faktor produksi sudah dapat menghasilkan sejumlah output yang telah ditentukan dengan penggunaan biaya yang telah ditentukan untuk mendapatkan keuntungan maksimum.

\section{KESIMPULAN DAN SARAN Kesimpulan}

Penerapan teknis budidaya pada usahatani padi sawah di Kabupaten Kuantan Singingi sudah hamper sesuai dengan teknis budidaya yang dianjurkan dengan besaran nilai kesesuaian adalah sebesar 81 persen untuk petani padi sawah jajar legowo dan sebesar 86 persen untuk petani padi sawah konvensional.

Biaya produksi usahatani padi sawah jajar legowo di Kabupaten Kuantan Singingi sebesar Rp. 19.828.378 per musim tanam per Ha, dengan total penerimaan sebesar Rp. 38.675.348 per musim tanam per Ha, maka diperoleh pendapatan bersih sebesar Rp. 18.846.970 per musim tanam per Ha nya dengan RCR sebesar 1,954. Biaya produksi usahatani padi sawah konvensional di Kabupaten Kuantan Singingi sebesar Rp. 18.571.963 per musim tanam per Ha, dengan total penerimaan sebesar Rp. 32.976.395 per musim tanam per Ha, maka diperoleh pendapatan bersih sebesar Rp. 14.404.432 per musim tanam per Ha nya dengan RCR sebesar 1,777 .

Petani padi sawah jajar legowo di Kabupaten Kuantan Singingi yang sudah efisien secara teknis berjumlah 46 persen, dengan nilai efisiensi teknis berkisar antara 0,810 - 1,000 dengan nilai rata-rata 0,965 , sedangkan petani padi sawah konvensional di Kabupaten Kuantan Singingi yang sudah efisien secara teknis berjumlah 51 persen, dengan nilai efisiensi teknis berkisar antara 0,787 - 1,000 dengan rata-rata 0,971 .

Petani padi sawah jajar legowo di Kabupaten Kuantan Singingi yang sudah efisien secara alokatif berjumlah 5 persen, dengan nilai efisiensi teknis berkisar antara 0,626 - 1,000 dengan nilai rata-rata 0,840 , sedangkan petani 
padi sawah konvensional di Kabupaten Kuantan Singingi yang sudah efisien secara teknis berjumlah 6,34 persen, dengan nilai efisiensi teknis berkisar antara $0,572-1,000$ dengan rata-rata 0,783 .

Petani padi sawah jajar legowo di Kabupaten Kuantan Singingi yang sudah efisien secara ekonomis berjumlah 5 persen, dengan nilai efisiensi teknis berkisar antara 0,570 1,000 dengan nilai rata-rata 0,811 , sedangkan petani padi sawah konvensional di Kabupaten Kuantan Singingi yang sudah efisien secara ekonomis berjumlah 6,35 persen, dengan nilai efisiensi teknis berkisar antara $0,572-1,000$ dengan rata-rata 0,760 .

Perbandingan efisiensi produksi usahatani padi sawah secara teknis lebih efisien sistem tanam konvensional dari pada sistem tanam jajar legowo berarti bahwa dalam pengolahan rata-rata petani padi sawah sistem tanam konvensional dalam penggunaan jarak tanam yang sesuai rekomendasi dari pada petani padi sawah sistem tanam jajar legowo sehingga dalam penggunaan benih dan pupuk lebih efisien, namun sistem tanam jajar legowo lebih efisien secara

\section{DAFTAR PUSTAKA}

Anggraini, F., A. Suryanto, dan N. Aini, 2013. Sistem Tanam dan Umur Bibit pada Tanaman Padi Sawah (Oryza sativa L.) Varietas Inpari 13. Jurnal Produksi Tanaman 5 (1): 52-60. Fakultas Pertanian. Malang: Universitas Brawijaya.

Aribawa, I. B. 2012. Pengaruh Sistem Tanam Terhadap Produktivitas Padi di Lahan Sawah Dataran Tinggi Beriklim Basah. Seminar Nasional : Kedaulatan Pangan alokatif dan ekonomis dari pada sistem tanam konvensional dikarenakan kemampuan petani padi sawah sistem tanam jajar legowo dalam menggunakan input dalam proporsi optimal terhadap harganya lebih optimal dibandingkan petani padi sawah sistem tanam konvensional sehingga mendapatkan keuntungan yang maksimum.

\section{Saran}

Penerapan teknis budidaya padi sawah sebaiknya mengikuti teknis budidaya yang sesuai dengan rekomendasi Balitbang Pertanian Dinas terkait juga memberikan penyuluhan dan bimbingan tentang pengaplikasian pupuk dan pengalokasian tenaga kerja secara optimal.

Untuk meningkatkan efisiensi teknis, alokatif dan ekonomis, maka petani disarankan untuk mengkombinasikan penggunaan input seperti benih, pupuk organik, pupuk anorganik, pestisida, dan tenaga kerja dengan proporsi yang lebih baik lagi serta dukungan pemerintah daerah setempat melalui dinas terkait seperti sosialisasi dan pelatihan teknis budidaya yang dapat diberikan oleh penyuluh pertanian lapangan.

dan Energi. Fakultas Petanian Universitas Trunojoyo Madura.

Arnanda, R. 2016. Efisiensi Produksi Padi di Kecamatan Kuala Kampar Kabupaten Pelalawan. Jurnal SOROT. 11(2) : 111-126.

Badan Penelitian dan Pengembangan Pertanian. 2016. Petunjuk Teknis Budidaya Padi Jajar Legowo Super. Jakarta : Balitbang Pertanian, Kementerian Pertanian Dendawijaya, L. 2001. Manajemen Perbankan. Jakarta : Ghalia Indonesia. 
Diratmaja A, Surdianto Y, Haryati Y. 2001.Keragaan teknologi cara tanam padi sistem legowo dalam mendukung sistem usahatani terpadu di Kabupaten Sukabumi. J.Sains \& Teknologi Vol 10.

Ikhwani. dkk. 2013. Peningkatan Produktivitas Padi Melalui Penerapan Jarak Tanam Jajar Legowo. Jakarta : Puslitbang Tanaman Pangan.

Pusat Penyuluhan Pertanian Badan Penyuluh dan Pengembangan SDM Pertanian. 2011. Budidaya Padi, Jakarta : BPSDM Pertanian Rebekka, L. dkk. 2015. Pengaruh Sistem Tanam Jajar Legowo Terhadap Pertumbuhan dan Produksi Beberapa Varietas Padi Sawah (Oryza sativa L.). Jurnal Agroekoteknologi FP USU. Medan

Saragih, V. B. 2015. Analisis Efisiensi Usahatani Padi Sawah Di Desa Sumber Tani Kecamatan Talawi Kabupaten Batu Bara: Suatu Pendekatan Stochastic Frontier.
Tesis Pascasarjana Universitas Sumatera Utara. Medan

Soekartawi. 2002. Prinsip Ekonomi Pertanian Teori dan Aplikasi. Jakarta : PT Raja Grafindo Persada.

Stephanie, H. 2012. Analisis Efisiensi Teknis dan Pendapatan Usahatani Padi Sawah Pendekatan Data Envelopment Analysis (DEA) Desa Kartawinangun Kecamatan Kadanghaur Kabupaten Indramayu. Departemen Agribisnis Fakultas Ekonomi dan Manajemen Institut Pertanian Bogor. Bogor.

Suharno. 2011. Sistem Tanam Jajar Legowo (Tajarwo) Salah Satu Upaya peningkatan Produktivitas Padi. Karya Ilmiah. STTP Yogyakarta.

Yoko, B. 2014. Analisis Efisiensi Usahatani Padi di Kabupaten Lampung Tengah. Jurnal Agribisnis Indonesia. 2(2) : 127140. 